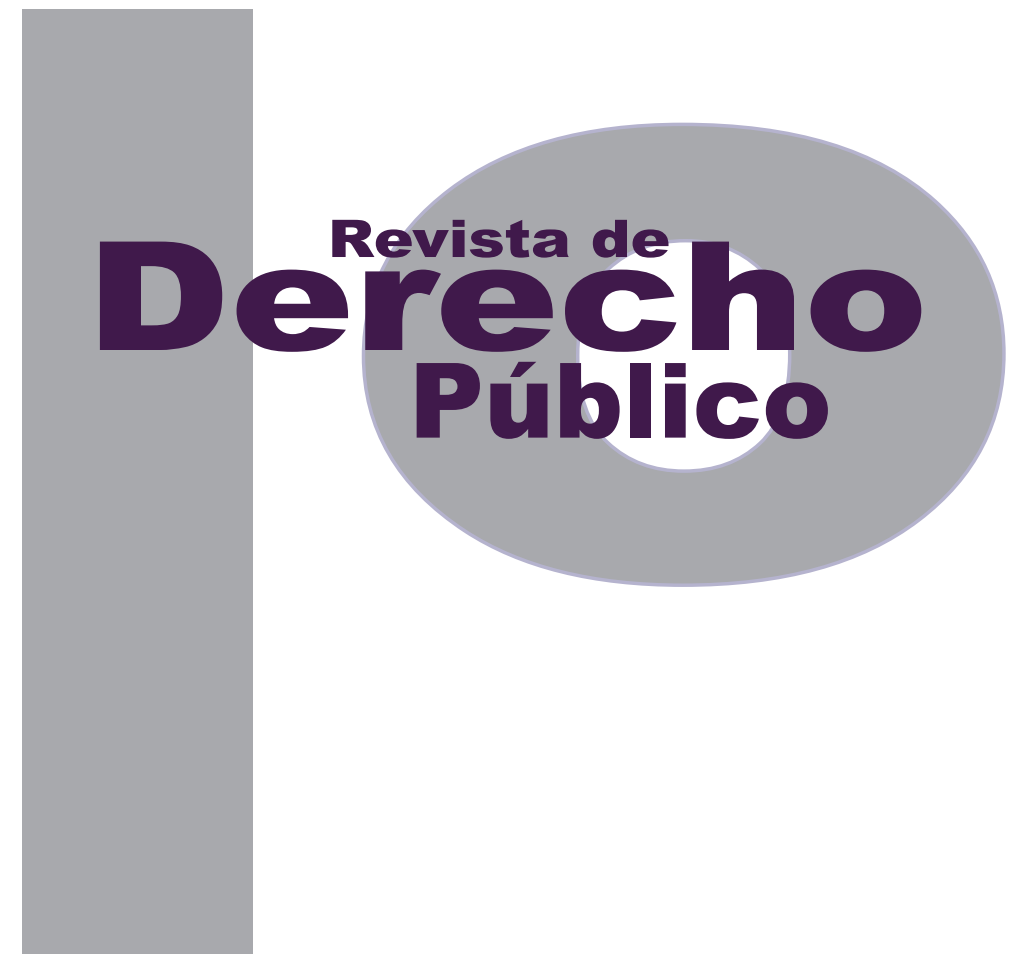

\title{
JURISDICCIÓN PENAL UNIVERSAL Y SU APLICACIÓN SOBRE CRÍMENES DE GUERRA COMETIDOS EN CONFLICTOS ARMADOS INTERNOS
}

\author{
PAula Andrea Guerrero Salazar
}

Artículo de reflexión

DOI: http://dx.doi.org/10.15425/redepub.33.2014.17

Universidad de los Andes

Facultad de Derecho

Revista de Derecho Público N. ${ }^{\circ} 33$

Julio - Diciembre de 2014. ISSN 1909-7778 


\title{
Jurisdicción penal universal y su aplicación sobre crímenes de guerra cometidos en conflictos armados internos
}

\section{Resumen}

El presente artículo examina el concepto de jurisdicción penal universal y su posible aplicación a crímenes de guerra cometidos en conflictos armados no internacionales que configuren una violación al artículo común 3 a las Convenciones de Ginebra de 1949. En la primera parte se aborda el análisis del concepto de jurisdicción universal desde las distintas posiciones asumidas por la jurisprudencia internacional. La segunda parte se ocupa, de manera concreta, de su posible aplicación a crímenes de guerra cometidos en conflictos armados internos que violan el artículo 3 común a las Convenciones de Ginebra de 1949. Bajo esa óptica, se incursiona en la práctica estatal dirigida tanto a la aplicabilidad de las normas internas de determinados Estados, como la jurisdicción universal de tribunales nacionales sobre crímenes de guerra cometidos en conflictos armados internos.

Palabras clave: jurisdicción universal, conflictos armados internos, crímenes de guerra, Artículo Común 3 de las Convenciones de Ginebra.

\section{Universal jurisdiction and its application over war crimes committed in non-international armed conflicts}

\begin{abstract}
This article examines the concept of universal criminal jurisdiction and the possibility of its application over war crimes committed in non-international armed conflicts that result in the violation of Common Article 3 of the Geneva Conventions of 1949. The first chapter focuses on the academic analysis of the international jurisprudence, especially over various judges' conclusions as to the international lawfulness of universal jurisdiction and on their treatment of the basic concept. The second chapter deals with the possible application of universal jurisdiction over war crimes committed in non-international armed conflict, which violate Common Article 3 of the Geneva Conventions of 1949. Consequently, after a preliminary comment on the definition of internal armed conflicts and the nature of war crimes, the article examines the case and legal practice of States in relation to its assertion of universal criminal jurisdiction over such heinous violations.
\end{abstract}

Keywords: universal jurisdiction, non-international armed conflicts, war crimes, Common Article 3 of the Geneva Conventions.

\section{Jurisdição penal universal e sua aplicação sobre crimes de guerra cometidos em conflitos armados internos}

\section{Resumo}

O presente artigo examina o conceito de jurisdição penal universal e sua possivel aplicação a crimes de guerra cometidos em conflitos armados não internacionais que configurem uma violação ao artigo comum 3 às Convenções de Genebra de 1949. Na primeira parte é abordada a análise do conceito de jurisdição universal desde as distintas posições assumidas pela jurisprudência internacional. A segunda parte se ocupa, de maneira concreta, de sua possível aplicação a crimes de guerra cometidos em conflitos armados internos que violam o artigo 3 comum às Convenções de Genebra de 1949. Sob essa ótica, se incursiona na prática estatal dirigida tanto a afirmar a aplicabilidade das normas internas de determinados Estados, quanto a jurisdição universal de tribunais nacionais sobre crimes de guerra cometidos em conflitos armados internos.

Palavras-chave: jurisdição universal, conflitos armados internos, crimes de guerra, Artigo Comum 3 das Convenções de Genebra. 


\title{
Jurisdicción penal universal y su aplicación sobre crímenes de guerra cometidos en conflictos armados internos*
}

\author{
Paula Andrea Guerrero Salazar ${ }^{*}$
}

\begin{abstract}
SUMARIO
Introducción - I. JURISDICCIÓN UNIVERSAL - A. Jurisdicción Universal prescriptiva y ejecutiva - B. Jurisdicción universal in absentia - C. Cláusula aut dedere aut judicare - II. JURISDICCIÓN PENAL UNIVERSAL SOBRE CRÍMENES DE GUERRA COMETIDOS EN CONFLICTOS ARMADOS NO INTERNACIONALES - A. Régimen de "infracciones graves" y otras violaciones - B. Opinión de algunos organismos internacionales sobre el ejercicio de jurisdicción universal sobre crímenes de guerra cometidos en conflictos armados internos - C. Práctica legal de los Estados - D. Práctica judicial - 1. Países Bajos - 2. Bélgica - 3. Francia - 4. Suiza - 5. Canadá - E. Valoración del derecho internacional consuetudinario - 1. Práctica de los Estados - 2. Opinio Juris - III. Conclusiones - Referencias.
\end{abstract}

* Cómo citar este artículo: Guerrero Salazar, P. A. (Diciembre, 2014). Jurisdicción penal universal y su aplicación sobre crímenes de guerra cometidos en conflictos armados internos. Revista de Derecho Público, 33. Universidad de los Andes (Colombia).

** Abogada y magister en Derecho Internacional de la Universidad de los Andes. Asesora en el despacho del Fiscal General de la Nación en temas de derecho internacional público. Las opiniones expresadas en este documento pertenecen a la autora y no comprometen la posición de la Fiscalía General de la Nación. Contacto: gpaulis888@gmail.com 


\section{Introducción}

Hasta hace algunos años la comunidad internacional negó la posibilidad de que las Cortes nacionales, ejerciendo jurisdicción universal, juzgaran crímenes de guerra cometidos en conflictos armados internos. De hecho, algunos sostuvieron que esto no era viable debido a que no tenían los elementos necesarios para generar responsabilidad penal individual de carácter internacional (Meron, 1995). Con el pasar del tiempo esta concepción ha cambiado. Esto se evidencia en la práctica de los Estados y en las variadas manifestaciones de organizaciones internacionales alusivas a la posibilidad, y de hecho a la necesidad, de que todos los Estados se comprometan con la lucha contra la impunidad juzgando a quienes cometan crímenes internacionales, como son los de guerra, incluso cuando son cometidos en conflictos armados internos.

Justamente es este continuo reconocimiento el que ha llevado a la comunidad internacional a tipificar estas conductas en los estatutos de Cortes internacionales, como ocurrió en el caso del Estatuto del Tribunal Penal Internacional para Ruanda, en el Tribunal Especial para Sierra Leona, y, más recientemente, en el Estatuto de Roma de la Corte Penal Internacional. Durante las negociaciones de este último, los agentes estatales fueron enfáticos en que la competencia de este tribunal internacional solo se activaría sobre los crímenes allí enlistados cuando el Estado o los Estados que tienen jurisdicción sobre estos no actúen. Siempre se advirtió que debe prevaler la jurisdicción de las Cortes na- cionales, siendo complementaria la de la Corte Penal Internacional.

El protagonismo de las Cortes nacionales en el juzgamiento de crímenes internacionales evidencia la importancia de la jurisdicción universal en la lucha contra la impunidad. Esta figura permite que los perpetradores de tales crímenes sean enjuiciados en una Corte nacional de cualquier Estado del mundo, a partir de la creencia de que el crimen cometido atenta contra valores vitales de la comunidad universal.

Así las cosas, el presente texto tiene dos objetivos principales: por un lado, estudiar y desarroIlar la figura de la jurisdicción universal, la cual, en variadas ocasiones, ha sido mal entendida en foros internacionales; por otro, determinar las posibilidades de la aplicación de esta figura a quienes cometan crímenes de guerra en conflictos armados de carácter interno, con base en el estudio de la práctica de los Estados y de algunas organizaciones internacionales.

\section{JURISDICCIÓN UNIVERSAL}

La jurisdicción es la potestad que tienen los Estados para afirmar la aplicabilidad de sus normas a ciertas circunstancias tempoespaciales. Tradicionalmente se han reconocido cuatro bases para ejercer jurisdicción penal: en primer lugar, la doctrina se ha referido a la jurisdicción territorial, la cual faculta a los Estados a ejercer jurisdicción sobre todos aquellos hechos que sucedan dentro de su territorio; en segundo lugar, se reconoce la jurisdicción personal, entendida como aquella que aplican los Estados 
sobre hechos cometidos por sus ciudadanos (personalidad activa) o en contra de ellos (personalidad pasiva); en tercer lugar, se reconoce la jurisdicción de principio protector que permite que los Estados se atribuyan jurisdicción sobre individuos que cometan actos que atenten contra intereses fundamentales del Estado, como por ejemplo, contra su seguridad, su orden económico o social, o su soberanía; finalmente, se habla de la jurisdicción universal, según la cual los Estados tienen capacidad para aplicar sus normas penales sobre hechos que no tienen ninguna conexión cercana con estos. En otras palabras, se trata de la posibilidad de ejercer jurisdicción sobre crímenes cometidos en el territorio de otro Estado, por y en perjuicio de extranjeros y que no atentan contra intereses fundamentales del Estado afirmante (Akehurst, 1974).

Esta última forma de jurisdicción, que es sobre la cual se concentra este documento, busca que los responsables de atacar valores de interés universal sean castigados debidamente. Para justificar su aplicación se ha argumentado que cuando se comete un crimen internacional la infracción no solo afecta al Estado territorial donde este ocurrió, sino que ese hecho trasciende fronteras, razón por la cual cualquier Estado puede perseguir legítimamente a los perpetradores. Al respecto, Werle sostiene que "los crímenes de derecho internacional no son asuntos internos y no rigen respecto de ellos los límites que el derecho internacional sienta a la expansión del poder punitivo del Estado, sobre todo en el marco del principio de no injerencia. En consecuencia, para los crímenes internacio- nales es válido el principio de universalidad" (2011, p. 137).

De la misma forma lo reconoció Grocio (1625) cuando expresó que las violaciones a las leyes del derecho natural constituían una ofensa en contra de toda la societas generis humani, es decir, en contra de toda la sociedad universal, y que, por tanto, todos los Estados tenían un interés, e incluso una obligación, de juzgar estos crímenes internacionales (citado en Rabinovitc, 2004). ${ }^{1}$

Ahora bien, el interés de que se juzgue a quienes cometan crímenes internacionales atroces, como son los crímenes de guerra, ha sido manifestado en repetidas ocasiones en foros internacionales por muchos gobiernos. Por ejemplo, en el seno de la Asamblea General de Naciones Unidas (2010) se sostuvo que el ejercicio de jurisdicción universal se relaciona directamente con el deber de los Estados de luchar contra la impunidad. $^{2}$

Este mismo deber fue reconocido por los Estados en 1998 al adoptar el Estatuto de Roma, el cual en su preámbulo reza: “los crímenes más graves de trascendencia para la comunidad in-

En el siglo XVII Grocio dijo que la soberanía no puede proteger a una persona de ser castigada cuando ha agredido a otro soberano. Para este jurista holandés, tras la denuncia de este último, el primero debe castigar o extraditar al responsable. Según Reydams (2010), la idea que hay detrás de los argumentos de Grocio es que no puede haber refugio seguro para los fugitivos de crímenes que atenten contra la humanidad en sí.

2 Países como El Salvador, Sur África, El Congo, Kenia, Tailandia, Perú, Noruega, Francia, Austria, Alemania, Finlandia, Bélgica, Túnez, Indonesia, Irán, Ruanda, Togo, entre otros, resaltaron el papel fundamental que juega la jurisdicción universal para combatir la impunidad y la búsqueda de la justicia (Asamblea General de las Naciones Unidas, 2010). 
ternacional en su conjunto no deben quedar sin castigo y que, a tal fin, hay que adoptar medidas en el plano nacional e intensificar la cooperación internacional para asegurar que sean efectivamente sometidos a la acción de la justicia”.

Es preciso aclarar que estos intereses de la comunidad internacional no solo se deben a la atrocidad del crimen, sino también a razones políticas o económicas de los Estados. Así las cosas, la persecución de crímenes como los de guerra, los de lesa humanidad o el genocidio radica en la primera premisa, es decir, la atrocidad. En otros casos, como por ejemplo, el seguimiento transnacional de crímenes como el de falsificación de moneda, el secuestro de aeronaves o el delito de piratería, se debe a intereses de otra naturaleza. ${ }^{3}$

Habiendo expuesto estas generalidades alrededor del concepto de jurisdicción universal, a continuación se abordan algunas tipologías de su ejercicio.

\section{A. Jurisdicción universal prescriptiva y ejecutiva}

Para la correcta comprensión del concepto de jurisdicción universal es preciso distinguir dos categorías: la jurisdicción prescriptiva y la jurisdicción ejecutiva. La jurisdicción universal pres-

3 Como señalan algunos autores, no se puede comparar la atrocidad de, por ejemplo, un crimen de genocidio con uno de falsificación de moneda, a pesar de que los dos son considerados crímenes internacionales sobre los cuales se puede ejercer la jurisdicción universal. De hecho, frente al crímen de piratería, que ha sido uno de los pocos sobre los que se considera indiscutible el ejercicio de la jurisdicción universal, la justificación radica en la dificultad de establecer otro tipo de jurisdicción, dado que su ejecución es en alta mar, donde ningún Estado tiene jurisdicción territorial. Ver, al respecto, Reydams (2010). criptiva, también conocida como jurisdicción legislativa, hace referencia a la posibilidad que tienen los Estados de afirmar la aplicabilidad de sus leyes, en este caso criminales, sobre determinada conducta delictiva extraterritorial. Es decir, se trata de la posibilidad de que un Estado criminalice en su derecho interno conductas que sean cometidas fuera de su territorio, frente a las cuales no tiene ninguna relación cercana de jurisdicción (0`Keefe, 2004).

Por su parte, la jurisdicción ejecutiva también llamada coercitiva, se refiere a la autoridad de un Estado bajo el derecho internacional para que efectivamente aplique su ley criminal por medio de acciones policivas y ejecutivas. Se trata, entonces, de la posibilidad de que las autoridades de un Estado detengan a personas por la comisión de actos criminalizados ( 0 `Keefe, 2004).

Ahora bien, cuando se hace referencia a la jurisdicción universal solo se habla de la primera categoría expuesta, es decir, de jurisdicción universal legislativa. Esto porque el derecho internacional prohíbe que los Estados realicen acciones policivas o ejecutivas en el territorio de otro Estado, pues una actuación así atentaría contra uno de los pilares máximos sobre los cuales se han fundamentado las relaciones internacionales, a saber: la igualdad soberana de todos los Estados y su integridad territorial (S. S. Lotus Fr. v. Turk., 1927).

Así, la jurisdicción universal solo abarca la posibilidad de que un Estado sostenga que sus normas penales aplican sobre actos extraterritoria- 
les y que estas sean ejercidas por un tribunal doméstico a través de una sentencia judicial, sin que el fallo pueda ser ejecutado o cumplido hasta que el acusado se encuentre en el fórum del Estado, ya que solo en ese caso las autoridades de este último podrán detenerlo para esos fines (O`Keefe, 2004).

Es preciso señalar que la forma de ejercicio de la jurisdicción universal depende única y exclusivamente de las leyes domésticas de los Estados. Por lo tanto, para que un Estado interesado en ejercer jurisdicción universal pueda hacerlo debe disponer en su derecho interno de las herramientas jurídicas que le permitan aplicar esa figura en el caso concreto (Arrest Warrant, 2000, opinión separada de los jueces Higgins, Kooijmans (...), párr. 56 ). ${ }^{4}$

A pesar de lo anterior, el primer interrogante que surge alrededor de la jurisdicción universal es si el derecho internacional permite u obliga a los Estados a que ejerzan su jurisdicción sobre hechos extraterritoriales con los cuales no tienen ninguna conexión directa. La jurisprudencia internacional ofrece algunas respuestas a esta cuestión. El tema se abordó por primera vez en

4 Así por ejemplo, aunque la obligación de perseguir o extraditar, la cual se abordará más adelante, se desprende del derecho internacional, su aplicación efectiva requiere que el Estado parte contemple en su derecho nacional las herramientas jurídicas que le permitan judicializar a alguien que ha cometido crímenes específicos en el extranjero. Al respecto puede verse el caso Questions Relating to the Obligation to Prosecute or Extradite Belgium v. Senegal (2012), en el cual se declaró que Senegal había incumplido sus obligaciones convencionales dispuestas en la Convención contra la Tortura al no haber adoptado a tiempo en su derecho doméstico leyes que le permitieran procesar y juzgar a quienes cometieran actos de tortura en el extranjero y que se encontraran en el fórum de su Estado. el caso S.S. Lotus, ${ }^{5}$ donde la Corte Internacional Permanente de Justicia reconoció que no existe una norma permisiva que autorice el ejercicio de la jurisdicción universal, pero como tampoco existe una que la prohíba, esta está permitida. En otras palabras, en Lotus se afirmó que los Estados son libres de extender su jurisdicción hasta donde deseen, siempre y cuando no transgredan una norma del derecho internacional. ${ }^{6}$

Una segunda ocasión donde se tocó el tema en sede internacional fue en el caso Arrest Warrant, ${ }^{7}$ en el cual algunos jueces de la Corte

5 En esa ocasión la disputa entre Francia y Turquía se dio debido al colapso de dos buques en alta mar, cada uno de los cuales izaba la bandera de uno de estos países respectivamente. A causa de la colisión el buque de vapor turco se hundió, causando la muerte de ocho ciudadanos turcos que se encontraban a bordo. La nave francesa "Lotus" al momento del accidente iba al mando de Monsieur Demons. Este último continuó su recorrido hasta Constantinopla, donde las autoridades turcas lo arrestaron preventivamente para asegurar su comparecencia ante las autoridades de ese país. Demons fue condenado a 80 días de prisión más multa por una Corte criminal de Turquía. Francia allegó el caso ante la Corte Permanente de Justicia solicitando que se declarara que las Cortes turcas no tenían jurisdicción penal para condenar a Demons, pues el accidente ocurrió en alta mar, lugar donde Turquía ni ningún otro país tiene jurisdicción. Turquía, por su parte, se defendió afirmando que el derecho internacional le permitía ejercer jurisdicción penal sobre Demons. En la parte resolutiva de la sentencia la Corte resuelve a favor del último. Aunque la decisión se tomó bajo la base de que la jurisdicción de Turquía sobre Demons era territorial y no universal, dado que los efectos del colapso de los buques se dieron en el que izaba bandera turca (sobre el cual se extiende la jurisdicción territorial de ese país), en este caso la Corte estudió la figura de la jurisdicción penal universal, afirmando que, como no existe ninguna regla en el derecho internacional que la prohíba, esta está permitida.

6 Justamente es ese límite el que no permite el ejercicio de la jurisdicción universal ejecutiva, pues esta transgrede los principios de soberanía e integridad territorial de los Estados, los cuales son considerados normas consuetudinarias y convencionales del derecho internacional (Carta de las Naciones Unidas, 1945).

$7 \quad$ Este litigio se dio a partir de una solicitud de arresto expedida por las autoridades belgas por crímenes cometidos fuera del territorio de ese país en contra de Abdoulaye Yerodia Ndombasi, que en ese entonces era el ministro de Relaciones Exteriores de la República Democrática del Congo. Frente a la actuación de Bélgica, el Congo se opuso rotundamente afirmando que ese país estaba violando el principio según el cual un Estado no puede ejercer autoridad en el territorio de otro. El caso fue allegado a la Corte Internacional de Justicia por el país africano, quien solicitó a la Corte que declarará que i) con esa solicitud de 
Internacional de Justicia, en sus opiniones separadas, reafirmaron la posición adoptada en el caso S. S. Lotus respecto a la posibilidad de ejercer jurisdicción universal in absentia, aceptando que esta estaba permitida porque no existe norma en el derecho internacional que la prohíba. ${ }^{8}$ Sin embargo, como se expondrá más adelante, se considera incorrecta la posición adoptada por estos jueces al hacer una distinción entre la jurisdicción universal y la jurisdicción universal in absentia.

Finalmente, la última manifestación que al respecto se ha hecho en la jurisprudencia internacional fue en la causa Preguntas relativas a la obligación de juzgar o extraditar (Questions Relating to the Obligation to Prosecute or Extradite, 2012). ${ }^{9}$ La sentencia se concentra en el estudio

arresto Bélgica no estaba respetando las inmunidades de las cuales era titular Mr. Yerodia, estipuladas por el derecho internacional; y ii) que se estaba violando el derecho internacional, pues Bélgica no podía juzgar in absentia a Mr. Yerodia. A pesar de lo anterior, al avanzar el proceso, la República del Congo retiró su segunda pretensión, por lo cual la Corte solo se pronunció respecto a la primera, resolviendo que efectivamente Mr. Yerodia no podía ser procesado en las Cortes belgas, ni en las de ningún otro país, debido a que era titular de inmunidades por ocupar un cargo oficial (canciller del Congo). Sin embargo, varios jueces en sus opiniones separadas trataron el tema de la jurisdicción universal. Para efectos del presente trabajo, se tendrán en consideración las manifestaciones de estos jueces, en especial las de Higgins, Kooijmans y Buergenthal y la del juez van den Wyngaert.

8 De hecho, en el caso concreto, estos jueces sostuvieron que no era posible el ejercicio de la jurisdicción universal in absentia por parte de Bélgica, pues de ser así, se transgredía una norma del derecho internacional relacionada con la inmunidad de los Estados y de sus agentes oficiales en las Cortes domésticas de otros Estados.

9 El caso versa sobre la denuncia de Bélgica ante la Corte Internacional de Justicia respecto al incumplimiento de Senegal de su obligación convencional de "perseguir o extraditar" a aquellos presuntos criminales que hubiesen cometido actos de tortura que se encuentren en su territorio. La acusación fue iniciada tras el hecho de que Senegal no procesó penalmente a Hissène Habré, expresidente del Chad, quien presuntamente cometió crímenes de lesa humanidad, tortura y desplazamiento forzado en su país de origen, y después estableció su residencia en Senegal. Bélgica, al haber iniciado procesos penales in absentia en contra de Habré, solicitó su extradición, pero esta fue de las obligaciones convencionales a partir de la cláusula aut dedere aut judicare, una de las fuentes del ejercicio de jurisdicción universal a partir de tratado. En su opinión separada el juez Abraham ${ }^{10}$ afirma que no existe una norma consuetudinaria en derecho internacional que obligue a Senegal, o a cualquier otro Estado, a que procese en sus Cortes nacionales crímenes internacionales extraterritoriales con los cuales no tenga ningún otro vínculo, incluso en el caso de tortura. ${ }^{11} \mathrm{El}$ juez sostiene que, a pesar del juicioso estudio presentado por Bélgica, donde suministra un listado de países que contemplan en su legislación nacional la jurisdicción universal sobre ciertos crímenes internacionales, ${ }^{12}$ esta es insuficiente para demostrar que efectivamente existe opinio juris de una obligación

negada por una Corte de Dakar. La Corte, al estudiar el caso, encontró que Senegal violó la convención contra la tortura, pues a pesar de haber realizado las reformas pertinentes para poder iniciar un proceso contra el expresidente extranjero, no inició la investigación. De alguna manera el fallo reconoce que la obligación que impone este tipo de tratados es que se investigue si efectivamente el sospechoso cometió los delitos que se alegan. Así mismo, se afirmó que para cumplir esta provisión convencional se deben adoptar las medidas domésticas para hacer posible tal persecución, esto es, prever el crimen internacional en la legislación nacional y establecer la base legal para la jurisdicción universal a nivel interno.

10 El juez consideró pertinente pronunciarse respecto a la afirmación que hacia Bélgica en cuando a la existencia de una norma internacional consuetudinaria que impone la obligación a los Estados de ejercer jurisdicción universal sobre ciertos delitos, a saber, crímenes de lesa humanidad, crímenes de guerra y genocidio (Memorial of the Kingdom of Belgium, 2010, p. 61 y ss.).

11 El juez es claro al señalar que la obligación respecto a este delito es de tratado y no una obligación consuetudinaria.

12 En un documento Bélgica suministró a la Corte Internacional de Justicia una lista de Estados que han incorporado en su legislación nacional provisiones que dan a sus Cortes "jurisdicción universal" para conocer de crímenes de guerra cometidos en el curso de conflictos armados no internacionales y de crímenes de lesa humanidad. Se encontró en total 51 países con esa legislación. Al respecto, consultar la opinión separada del juez Abraham, en Questions Relating to the Obligation to Prosecute or Extradite, 2012. 
consuetudinaria de los Estados para ejercer tal jurisdicción. ${ }^{13}$

De los pronunciamientos jurisprudenciales mencionados se pueden sacar dos conclusiones: (i) los Estados pueden ejercer jurisdicción universal siempre y cuando esta no transgreda una norma de derecho internacional, como por ejemplo, que se respeten las inmunidades y la soberanía de los otros Estados; (ii) aunque la jurisdicción universal está permitida, su ejercicio solo obliga cuando exista una norma de derecho internacional convencional o consuetudinario que así lo disponga, de lo contrario, esto solo será una potestad de los Estados.

\section{B. Jurisdicción universal in absentia}

La jurisdicción universal in absentia es una de las formas como se puede ejercer la jurisdicción universal. En este caso, se trata de juzgar a un extranjero que se encuentra ausente, por un crimen cometido fuera del territorio del Estado afirmante, contra un ciudadano de otro país y por un crimen que no afecta intereses fundamentales del Estado (0`Keefe, 2004).

13 Según el juez, esto se debe a tres razones. En primer lugar, los Estados en cuestión solo representan una minoría dentro de la comunidad internacional, lo cual es insuficiente para establecer la existencia de una regla consuetudinaria universal. Segundo, algunos de estos Estados pueden haber adoptado esa legislación bajo la base de una interpretación particular de sus obligaciones convencionales, pero cierta interpretación no es universalmente compartida, pues otros Estados parte de las mismas convenciones no han tomado las mismas acciones. Por lo tanto, eso no demuestra la existencia de una opinio juris al respecto, es decir, una creencia de que existe una obligación consuetudinaria de establecer "jurisdicción universal". Tercero, puede ser que algunos de estos 51 Estados hayan decidido extender la jurisdicción de sus Cortes sobre los crímenes en cuestión, bajo la base de una decisión unilateral puramente soberana, sin ninguna creencia de estar obligados a hacerlo consuetudinariamente (opinión separada del juez Abraham, párrs. 35 y ss. en Questions Relating to the Obligation to Prosecute or Extradite, 2012)
La jurisprudencia internacional se ha referido a esta forma de jurisdicción de manera errónea. En el caso Arrest Warrant se presenta la jurisdicción universal in absentia como si se tratara de un tipo diferente a la jurisdicción universal. ${ }^{14}$ Esto se evidencia en el hecho de que los jueces se esmeran en justificar de manera separada la posibilidad o imposibilidad, en el derecho internacional, de ejercer jurisdicción in absentia por parte de los Estados. Para estos jueces, la posibilidad de que el derecho internacional apruebe el ejercicio de la jurisdicción universal no quiere decir que ocurra lo mismo respecto a la jurisdicción universal in absentia.

Tal distinción se considera desacertada porque, como ya se dijo, la aplicación de la jurisdicción universal prescriptiva se refiere a que un Estado afirme la aplicabilidad de sus normas penales sobre un crimen que, al momento de su comisión, no tiene ninguna otra relación con este Estado, es decir, que el hecho fue cometido fuera de su fórum, por una persona que al momento de cometer el acto no era su ciudadana, en perjuicio de personas que tampoco son nacionales del Estado en cuestión. Lo anterior es completamente independiente de la circunstancia de que, para aplicar una ley nacional sobre el presunto criminal (jurisdicción legislativa), la norma exija que el individuo comparezca o no al proceso. En otras palabras, lo que el derecho internacional permite es el ejercicio de la jurisdicción universal en términos generales y no un tipo o clase de ella. La jurisdicción in absentia

14 O’keefe hace referencia expresamente a las opiniones de Higgins, Kooijmans y Buergenthal, así como a las de Ranjeva, Rezec, Guillaume y la de Van de Wyngaert. 
no es una especie, sino una forma de ejercicio de esta, que solo compete a los Estados soberanos implementar, pues cada uno es libre de determinar las reglas y los requisitos que van a imperar en sus tribunales internos al momento de juzgar crímenes extraterritoriales.

Esta diferenciación es más directa cuando los jueces Higgins, Kooijmans y Buergenthal afirman que el ejercicio de la jurisdicción sobre un individuo que se encuentra presente en el territorio por actos extraterritoriales, no es jurisdicción universal sino territorial (Arrest Warrant, 2000, opinión separada de los jueces Higgins, Kooijmans (...), párr. 41). Al inicio de este trabajo se estableció que la jurisdicción territorial en materia penal se refiere a la posibilidad de que un Estado afirme, aplique y ejecute sus leyes penales sobre todos aquellos actos criminales que sean cometidos dentro de su territorio. Por lo tanto, es erróneo sostener que se está en aplicación de la jurisdicción territorial cuando un Estado afirma, aplica y ejecuta sus normas penales a un hecho que tuvo lugar fuera del territorio de dicho Estado y con el cual, al momento de su ejecución, no tenía ninguna conexión.

En este escenario, el único Estado que podría ejercer jurisdicción territorial es aquel donde se cometieron los delitos. La circunstancia de que después de la comisión de las conductas el presunto criminal abandone el territorio de ejecución y se refugie en otro, no quiere decir que a este último se le traspasa la posibilidad de ejercer jurisdicción territorial, pues esta permanece en cabeza del Estado donde se cometieron los hechos. Sin embargo, el Estado donde el crimi- nal se asienta, ya sea de paso o como residente, si cuenta con la reglamentación adecuada, podría ejercer su jurisdicción extraterritorial, ya sea porque el presunto autor es ciudadano de su Estado (nacionalidad activa), o porque los afectados son sus nacionales (nacionalidad pasiva), o porque el acto criminal afectó directamente los intereses fundamentales de su Estado (principio protector), o simplemente, porque su legislación nacional le permite ejercer jurisdicción universal sobre el hecho, siempre y cuando se den las condiciones que justifican su aplicación.

\section{Cláusula aut dedere aut judicare}

Otra forma de ejercer jurisdicción universal se desprende de la cláusula conocida como aut dedere aut judicare, contenida en algunas convenciones internacionales. Esta cláusula se caracteriza por obligar a las Altas Partes Contratantes a que, en caso de que en su territorio se refugie el autor de un crimen internacional, el Estado está en la obligación de perseguirlo, esto es, investigar y hacer que comparezca ante un juez nacional para que determine su responsabilidad penal. En caso de que el Estado no quiera iniciar procesos o no esté en condiciones de hacerlo, por ejemplo, por no contar con las normas nacionales que se lo permitan, debe extraditarlo a un Estado que pueda y quiera hacerlo, pues de lo contrario se genera una violación del respectivo tratado (Questions Relating to the Obligation to Prosecute or Extradite, 2012).

Ahora bien, cuando se trata de la cláusula aut dedere aut judirare, el ejercicio de jurisdicción universal pasa de ser una potestad a una obli- 
gación del Estado, pues de lo contrario este, al no juzgar o extraditar al responsable de la comisión de crímenes internacionales, incumplirá una obligación convencional, pudiendo verse comprometida su responsabilidad por un hecho ilícito internacional.

Bajo esta cláusula, la obligación del Estado de ejercer jurisdicción nace cuando el individuo responsable se encuentra en su territorio. Es decir, que mientras el autor de los crímenes se encuentre fuera de su territorio, el Estado puede decidir si inicia o no procesos en su contra; pero cuando el presunto criminal se halle en su país, esa potestad pasa a ser una obligación, la cual solo puede ser reemplazada por la opción de entregar al criminal a otro Estado que sí quiera y pueda procesarlo por los hechos criminales (Council of the European Union, 2009, párr. 13).

Frente a esta forma de ejercicio de jurisdicción universal también se han presentado algunos malos entendidos. Por ejemplo, en su opinión separada en el caso Arrest Warrant los jueces Higgins, Kooijmans y Buergenthal niegan que en este caso se trate del ejercicio de jurisdicción universal, por tratarse de jurisdicción territorial o jurisdicción de tratado. Esta posición resulta incorrecta en la medida que, incluso en aplicación de esta cláusula, se está afirmando jurisdicción sobre crímenes que, al momento de su comisión, no tenían ninguna conexión con el Estado afirmante, esto independientemente de que al ejercerse la jurisdicción el criminal se encuentre en su fórum. Además, el hecho de que la obligación de ejercer jurisdicción en estos ca- sos se desprenda de un tratado, no quiere decir que su naturaleza de universal cambie.

Así las cosas, todo indica que el derecho internacional permite que los Estados ejerzan jurisdicción universal frente a ciertos crímenes, en los cuales la impunidad es inaceptable por la comunidad internacional. Además, cuando los Estados se obligan por convenciones internacionales que tienen como objetivo la lucha contra la comisión y la impunidad de este tipo de hechos, apoyan, de alguna manera, la existencia de esta base de jurisdicción.

\section{JURISDICCIÓN PENAL UNIVERSAL SOBRE CRÍMENES DE GUERRA COMETIDOS EN CONFLICTOS ARMADOS NO INTERNACIONALES}

El tema se torna aún más complejo cuando se trata de ejercer jurisdicción universal respecto a crímenes de guerra cometidos en conflictos armados internos, por dos razones: en primer lugar, por muchos años los Estados consideraron que la regulación y el manejo de las guerras civiles era una cuestión que solo interesaba al Estado donde se presentaban y que, por lo tanto, la intervención configuraba una intromisión en los asuntos internos y los poderes soberanos; en segundo lugar, en las Convenciones de Ginebra de 1949, que son las que por excelencia regulan el derecho de la guerra entre y dentro de Ios Estados, solo se contempló expresamente la obligación de ejercer jurisdicción universal respecto a los crímenes de guerra que pertenecen al régimen de infracciones graves, atados a los 
conflictos armados internacionales. En ellas se guardó silencio sobre la posibilidad de ejercer ese tipo de jurisdicción sobre crímenes de guerra cometidos en conflictos armados internos, como por ejemplo, los contemplados en el artículo común 3.

Ahora bien, en cuanto a la naturaleza jurídica de las infracciones contendidas en el artículo común 3 , puede decirse que estas configuran crímenes de guerra ocurridos en conflictos armados internos. ${ }^{15}$ Esto significa que su violación genera responsabilidad penal internacional para quien lleve a cabo esos actos (Comité Internacional de la Cruz Roja, 2007). Tal posición ha sido puesta de manifiesto en varias ocasiones. En 1994 el Consejo de Seguridad de las Naciones Unidas expidió el Estatuto del Tribunal Penal Internacional para Ruanda, cuyo artículo 4 criminaliza las "violaciones serias al Artículo Común 3 de las Convenciones de Ginebra y las del Protocolo Adicional II". Ello implicó una gran innovación porque el texto del Estatuto del Tribunal Penal Internacional para la ex Yugoslavia (en adelante ıстY, por sus siglas en inglés), expedido con anterioridad, no contempló la posibilidad de que el Tribunal ejerciera jurisdicción sobre las infracciones al derecho de la guerra en conflictos armados internos (Meron, 1995). A pesar de lo anterior, el ıcTy en el caso Tadić afirmó que, por disposición del derecho internacional consuetudinario, las infracciones al artículo común 3 configuran crímenes internacionales que por

15 Esto último ha sido establecido por el estudio de derecho internacional consuetudinario auspiciado por el Comité Internacional de la Cruz Roja. Este afirma que las violaciones graves al derecho internacional humanitario, ya sean cometidas en conflictos armados internacionales o internos, constituyen crímenes de guerra. supuesto conllevan a la responsabilidad penal individual de su perpetrador (Presecutor $v$. Tadić, 1995, párrs. 129 y 134).

Finalmente, la criminalidad internacional de las violaciones al derecho de la guerra cometidas en conflictos de carácter interno se ve confirmada por la tipificación de estas conductas en el Estatuto de Roma de la Corte Penal Internacional (Estatuto de Roma, 1998, art. 8)2)c)).

\section{A. Régimen de "infracciones graves" $y$ otras violaciones}

Las Convenciones de Ginebra de 1949 establecieron en su texto una diferencia tangencial respecto al tratamiento de los crímenes de guerra cometidos en conflictos armados internacionales frente a los que ocurren en conflictos internos. La diferencia más relevante es la que se genera a partir del régimen de "infracciones graves". Estas últimas determinan cierto grupo de actos que se consideran de mayor gravedad, cometidos en conflictos armados internacionales. Frente a estos se incluyó la cláusula aut dedere aut judicare, ${ }^{16}$ lo cual se traduce en el reconocimiento convencional de la obligación de ejercer jurisdicción penal universal respecto a tales violaciones. ${ }^{17}$ Dado que el artículo común 3 no hace parte de la categoría de "infracciones graves", y que la misma cláusula no fue estipu-

16 Esta cláusula solo se incluyó respecto a las "infracciones graves" a las Convenciones de Ginebra. Estas últimas están contenidas en los artículos 50 de la Primera Convención de Ginebra, 51 de la Segunda, 130 de la Tercera y 147 de la Cuarta.

17 La cláusula aut dedere aut judicare frente a las infracciones graves está contenida en los artículos 49 de la Primera Convención de Ginebra, 50 de la Segunda, 129 de la Tercera y 146 de la Cuarta. 
lada frente a este, no existe un reconocimiento expreso convencional respecto al deber de ejercer jurisdicción universal sobre los crímenes de guerra contenidos en ese artículo en conflictos internos.

A pesar de lo anterior, es preciso anotar que tal posibilidad tampoco se prohibió. De hecho, las Convenciones de Ginebra solicitan a los Estados que tomen las medidas necesarias para suprimir todos aquellos actos que sean contrarios a las provisiones de ese instrumento internacional, incluidos los que no son considerados infracciones graves. ${ }^{18}$

\section{B. Opinión de algunos organismos internacionales frente al ejercicio de jurisdicción universal sobre crímenes de guerra cometidos en conflictos armados internos}

En los años noventa algunos organismos internacionales como el Comité Internacional de la Cruz Roja ${ }^{19}$ y las Naciones Unidas ${ }^{20}$ considera-

18 Los mismos artículos que establecen la obligación aut dedere aut judicare en cada una de las Convenciones de Ginebra, determinan en su tercer inciso que "[c]ada Parte Contratante tomará las oportunas medidas para que cesen, aparte de las infracciones graves definidas en el artículo siguiente, los actos contrarios a las disposiciones del presente Convenio".

19 Al respecto, en sus comentarios del 25 de marzo de 1993 al borrador del Estatuto del Tribunal Penal Internacional para la ex Yogoeslavia, el Comité Internacional de la Cruz Roja aseguró que "de acuerdo con el derecho internacional humanitario actual, la noción de crimen de guerra está limitada a las situaciones de los conflictos armados internacionales" (Meron, 1995).

20 Como ejemplo se puede hacer mención de la manifestación del Consejo de Seguridad de Naciones Unidas cuando en 1992, en el Reporte Final de la Comisión de Expertos establecida en virtud de la Resolución 780 de 1992, afirmó que las únicas ofensas que se pueden cometer en los conflictos armados internos, a las cuales les aplica la jurisdicción universal, son los crímenes de lesa humanidad y el genocidio, delitos en los que se ejerce independientemente de la clasificación del conflicto (Doc. S/1994/674, 27 de mayo de 1992, párr. 42). ban que los crímenes cometidos en conflictos armados internos no conllevaban la responsabilidad penal internacional y mucho menos la posibilidad de ejercer jurisdicción universal. Con el correr de los años esa opinión ha cambiado, al punto que hoy día tales organismos, y muchos otros, reconocen la criminalidad de los quebrantamientos al derecho de la guerra cometidos en conflictos internos y su posible persecución bajo la figura de la jurisdicción universal.

Por ejemplo, en el año 2000, Human Rights Watch sostuvo que "en los años recientes, el concepto de crimen de guerra se ha ido extendiendo a los conflictos armados internos, concediendo a terceros Estados el derecho de ejercer jurisdicción universal respecto a esos crímenes" (2000, p. 7). Por su parte, el estudio auspiciado por el Comité Internacional de la Cruz Roja sobre derecho internacional consuetudinario (2007), estableció en su regla n. ${ }^{\circ} 157$ que los Estados tienen derecho a conferir a sus tribunales nacionales jurisdicción universal en materia de crímenes de guerra cometidos en conflictos armados internacionales e internos. De igual forma, el Instituto de Derecho Internacional sostuvo que la jurisdicción universal debe ser ejercida sobre crímenes internacionales, en los que incluyó las violaciones serias al derecho internacional humanitario cometidas en los conflictos armados no internacionales (2005, Reporte n. $^{\circ}$ 3). Este criterio también fue acogido por la Association of International Law, quién encontró que las violaciones serias al artículo común 3 de las Convenciones de Ginebra son actos criminales que están cubiertos por el principio de jurisdicción universal (2000). 


\section{Práctica legal de los Estados}

En los últimos años, muchos Estados han decidido incluir en sus legislaciones penales la jurisdicción universal de sus Cortes respecto a crímenes de guerra cometidos en conflictos armados internos.

Para la presente investigación se tomó como muestra la práctica de cincuenta Estados. A partir de su observación se pueden distinguir cinco tipos de legislaciones: (i) las que explícitamente afirman jurisdicción universal sobre crímenes de guerra cometidos en conflictos armados no internacionales; (ii) las que establecen esa jurisdicción sobre los crímenes que se encuentran en el Estatuto de Roma; (iii) las que autorizan ese tipo de ejercicio de jurisdicción sobre crímenes de guerra sin diferenciar aquellos cometidos en conflictos armados internos o internacionales; (iv) las que confieren jurisdicción universal únicamente respecto a los crímenes de guerra que configuran una infracción grave a los Convenios de Ginebra de 1949; y (v) las legislaciones que solo afirman su jurisdicción universal en aquellos casos en los que sea una obligación impuesta por una norma de derecho internacional convencional.

En el primer grupo encontramos países como Holanda, que en las secciones 1 y 6 del Acta de Crímenes Internacionales de 2003 establece expresamente la jurisdicción universal de sus Cortes respecto a criminales que cometan violaciones al artículo común 3 de las Convenciones de Ginebra en el transcurso de un conflicto ar- mado interno. ${ }^{21}$ Igual ocurre en las legislaciones de Burundi, Canadá, Alemania, Rumania, Bélgica, Nicaragua, El Salvador, Finlandia, Suiza y Eslovenia (ver anexo).

El segundo grupo incluye países como Francia, que en el 2010 modificó su Código Penal y de Procedimiento para ajustar su legislación al Estatuto de Roma, afirmando la jurisdicción universal de sus Cortes sobre los diferentes crímenes tipificados en el Estatuto de la Corte Penal Internacional (Ley 930 del 9 de agosto de 2010). ${ }^{22}$ Esto mismo ocurre en Croacia, República Democrática del Congo, Nueva Zelanda, Australia, Sur África, Argentina, Uruguay, Eslovaquia, Portugal y Chipre (ver anexo).

Finalmente, encontramos un grupo de Estados que afirman el principio de jurisdicción universal de sus normas penales sobre crímenes de guerra pero que en su legislación no distinguen entre aquellos cometidos en conflictos armados internacionales o en guerras civiles. Este es el caso de países como Azerbaiyán, Belarus, CoIombia, Costa Rica, Dinamarca, Estonia, Etiopía, Georgia, Lituania, España, Tayikistán, Suecia, Polonia, Noruega, Luxemburgo, República Checa y Bulgaria (ver anexo).

Ahora bien, de los cincuenta Estados estudiados para la presente investigación, encontra-

21 Debe anotarse que la ley anterior, a saber, la Wartime Act de 1952, también afirmaba el principio de jurisdicción universal de las Cortes holandesas sobre crímenes de guerra cometidos en conflictos no internacionales. Ver Ryngaert, C. (2007).

Los requisitos para el posible ejercicio de la jurisdicción universal en estos casos es que el presunto criminal resida en Francia, que la investigación sea iniciada por el fiscal general, así como la subsidiariedad y la doble incriminación. 
mos diez que no contemplan la aplicabilidad universal de sus normas penales sobre infracciones al artículo común 3 de las Convenciones de Ginebra. Entre estos se encuentra Hungría, Irlanda, Rusia, Estados Unidos, Reino Unido, Grecia, Austria, Perú, Brasil e Italia (ver anexo).

Así las cosas, se puede sostener que la práctica de los Estados en esta materia no es uniforme, sino por el contrario muy variada. Por un lado, se encuentran Estados que reconocen expresamente esta posibilidad, sobre los cuales no cabe duda de su aceptación y contribución al establecimiento de una regla consuetudinaria a favor de ese ejercicio. Otros, a pesar de no oponerse expresamente a esa práctica, no participan explícitamente de ella, dado que la ambigüedad de los términos legales que utilizan en sus legislaciones penales no permite determinar una posición certera al respecto. Finalmente, está un grupo de Estados que tiene una práctica completamente contraria, pues es claro que sus legislaciones internas no permiten el ejercicio de esa forma de jurisdicción sobre los crímenes que nos conciernen. Así las cosas, la práctica de los Estados en el tema debatido no puede considerarse uniforme ni extendida.

\section{Práctica judicial}

\section{Países Bajos}

Las Cortes criminales holandesas en repetidas ocasiones han asumido investigaciones y juzgado a criminales extranjeros por crímenes de guerra que atentan contra el artículo común 3 de las Convenciones de Ginebra bajo el principio de jurisdicción universal.
Un primer caso es el del Fiscal v. Darco Knczevic, un bosnio serbio refugiado en Holanda de quien se sospechaba que había cometido crímenes de guerra durante el conflicto en la antigua Yugoslavia. El fiscal estableció que en ese caso el conflicto armado era de carácter interno. A pesar de que el juez de instrucción que conoció en primera instancia consideró que las Cortes holandesas no tenían jurisdicción, la Corte Suprema de ese país determinó que la Wartime Act sí era aplicable al caso, afirmando la posibilidad de que sus jueces ejercieran jurisdicción universal sobre violaciones al derecho de la guerra en conflictos internos (sentencia de la Corte Suprema holandesa del 11 de noviembre de 1997, en Reydams, 2004).

El segundo caso encontrado data de 2005. En él, la Corte del Distrito de La Haya procesó penalmente a dos exoficiales militares afganos que estaban exiliados en Holanda. Estos fueron acusados de haber cometido tortura y violaciones al artículo común 3 durante la guerra en Afganistán, entre los años 1978 a 1996. En este caso, el tribunal consideró que el conflicto armado ocurrido en ese país era de carácter interno. De igual forma, la Corte del Distrito afirmó la posibilidad de aplicar las normas penales establecidas en la Wartime Act de 1952 y el Acta de Crímenes Internacionales de 2003, bajo el principio de jurisdicción universal a los dos nacionales afganos (Ryngaert, 2007).

2. Bélgica

La primera vez que Bélgica apeló a la jurisdicción universal para procesar a presuntos auto- 
res de crímenes de guerra fue en el caso Butare Four (Fiscal Público v. Butare Four, 2001). Este juicio inició el 17 de abril de 2001 en una Corte de Bruselas, donde se procesó a los criminales por su presunta participación en un trágico evento en Butare (Ruanda): un grupo de tutsis, tratando de salvaguardar sus vidas, se refugiaron en un convento donde fueron asesinados tras varios ataques. En el presente caso Bélgica no podía extraditar al acusado a Ruanda por ausencia de tratado de extradición y, por su parte, el Tribunal Penal Internacional para Ruanda había decidido no iniciar proceso contra estos individuos. Debido a ello, Bélgica asumió el juzgamiento de los cuatro criminales (Wilt, 2011).

\section{Francia}

Los casos en los que las Cortes francesas han ejercido jurisdicción universal por la vulneración del artículo común 3 de las Convenciones de Ginebra se relacionan, única y exclusivamente, con delitos cometidos en los conflictos armados de la antigua Yugoslavia y Ruanda. En ellos la jurisdicción se ejerció a partir de las leyes de 1995 y 1996 que implementaron las resoluciones adoptadas por el Consejo de Seguridad de la onu para enfrentar la crisis humanitaria en esos países. ${ }^{23}$ Según la Corte de Casación francesa esas normas le conferían a los tribunales nacionales jurisdicción universal para juzgar a los autores de crímenes de guerra, genocidio y

23 Por medio de estas resoluciones el Consejo de Seguridad de las Naciones Unidas creó los tribunales Internacionales ad hoc para la antigua Yugoslavia (Resolución 827 del 25 de mayo de 1993) y para Ruanda (Resolución 955 del 8 de noviembre de 1994). Estas incoaban a los Estados a cooperar con la labor de esas corporaciones, adoptando en su derecho interno las herramientas que les permitieran hacerlo. lesa humanidad, siempre que estos se encontraran en territorio francés ${ }^{24}$ (Re Javor, 1996, párr. 132 en La Haye, 2008).

\section{Suiza}

En 1997, un tribunal militar suizo condenó a un serbio bosnio por infracciones a las Convenciones de Ginebra durante el conflicto en la antigua Yugoslavia, al cual caracterizó como internacional. ${ }^{25}$ Sin embargo, en esa ocasión el tribunal afirmó que tenía jurisdicción para conocer de estos delitos, incluso si ellos hubiesen sido cometidos en un conflicto armado interno (Fiscal Militar v. Gabrez, 1997 en La Haye, 2008). Un año después, el mismo tribunal halló responsable penalmente, bajo el principio de jurisdicción universal, a un refugiado ruandés que, entre otros delitos, cometió infracciones al artículo común 3, por lo que fue condenado a catorce años de prisión ${ }^{26},{ }^{27}$ (sentencia del 26 de mayo del 2000 en La Haye, 2008).

24 El único caso en el que efectivamente se condenó al autor de crímenes de guerra cometidos en el conflicto armado interno en Ruanda fue en el de Munyeshyaka.

25 En este caso el demandado era acusado de asesinar y herir a varios civiles que estaban detenidos en el campo de concentración de Omarska y Keraterm en Bosnia, en 1992. Debido a que no hubo suficiente evidencia para establecer la responsabilidad del acusado, este fue declarado inocente.

En ambos casos la jurisdicción se ejerció a partir del artículo 109 del Código Penal Militar suizo.

27

Tambien en este país se está procesando penalmente a Khaled Nezzar, un exministro de Defensa y alto consejero de Estado argelino, sospechoso de haber cometido crímenes de guerra y tortura durante la guerra civil en Argelia. Este hombre fue detenido mientras asistía a un tratamiento médico en Suiza. La Corte Penal Federal de ese país estableció, el 25 de julio de 2012, que Nezzar no gozaba de ninguna inmunidad personal o material como alegaba. Este caso aún no ha sido fallado, pero por la práctica de las Cortes suizas puede terminar en un juicio por crímenes de guerra cometidos en conflictos armados internos (decisión de la Corte Penal Federal Suiza, 2012, disponible en http://www.asser.nl/upload/documents/20130221T040104Nezzar Judgm_Eng_translation\%2025-07-2012.pdf) 


\section{Canadá}

En el año 2005, Désiré Munyaneza, un ruandés que se encontraba en territorio canadiense pidiendo asilo, fue acusado por cometer genocidio, crímenes de lesa humanidad y crímenes de guerra, durante el conflicto ruandés de los años noventa. En el 2009, la Corte Suprema de Quebec lo declaró culpable de todos los cargos imputados (Fiscal v. R.c. Munyaneza, 2009). También en ese año las autoridades canadiences arrestaron a Jacques Mungwarere, un asilado ruandés sospechoso de haber participado en el genocidio en Ruanda. En mayo de 2010, Mungwarere fue acusado de cometer crímenes contra la humanidad y crímenes de guerra (homicidio y violencia sexual). Sin embargo, el 15 de julio de 2013 el Tribunal canadiense lo declaró inocente, asegurando que no se había demostrado su culpabilidad más allá de toda duda razonable. ${ }^{28}$

\section{E. Valoración del derecho internacional consuetudinario}

El Estatuto de la Corte Internacional de Justicia define la costumbre internacional como una práctica generalmente aceptada como derecho (art. 38 (1)(b)). Para determinar la existencia de una costumbre internacional se requiere la presencia de dos elementos: i) la práctica de los Estados; y ii) la opinio juris, esto es, la creencia de que esa práctica corresponde a un derecho

28 En ambos casos las autoridades judiciales canadienses ejercieron jurisdicción universal a partir de Crimes Against Humanity and War Crimes Act, de 2000. o a una obligación (Comité Internacional de la Cruz Roja, 2007).

\section{Práctica de los Estados}

En cuanto al primer elemento, la presente investigación tuvo en cuenta los actos verbales oficiales de cincuenta Estados que contribuyen o se oponen al establecimiento de una costumbre internacional, respecto al ejercicio de la jurisdicción universal sobre crímenes de guerra cometidos en conflictos armados internos que atenten contra el artículo común 3. Estos actos incluyen manuales militares, legislación penal nacional, jurisprudencia de Cortes nacionales, alegatos ante tribunales internacionales, declaraciones de los Estados en las organizaciones internacionales y sus posiciones frente a resoluciones adoptadas en el seno de estas. ${ }^{29}$ De igual forma, se consideró la práctica de algunas organizaciones internacionales que gozan de reconocimiento jurídico y, por tanto, pueden participar en las relaciones internacionales y contribuir a la formación del derecho internacional consue-

29 Tal y como fue afirmado en el estudio de derecho internacional consuetudinario realizado por el CICR, los actos verbales son prueba de la práctica de los Estados frente a cierta situación (Comité Internacional de la Cruz Roja, 2005, p. xxxix). Esto ha sido reconocido en la jurisprudencia de la Corte Internacional de Justicia en los casos Jurisdicción Pesquera (Reino Unido v. Islandia), 1974; en el caso concerniente a las actividades militares y paramilitares en y en contra de Nicaragua (Nicaragua v. Estados Unidos), 1986; y en el caso relacionado con el Proyecto Gabcikovo-Nagymaros (Hungría v. Eslovaquia), 1997. Lo mismo fue reconocido por el ICTY, que en el caso Tadic afirmó que la formación de las reglas de derecho internacional consuetudinario depende primordialmente de las declaraciones oficiales de los Estados, los manuales militares y las decisiones judiciales (Presecutor v. Tadić. Decision on the Defense Motion for Interlocutory Appeal on Jurisdiction, 1995, párr. 99, tomado de Comité Internacional de la Cruz Roja, 2005). Por su parte, la Asociación de Derecho Internacional consideró que los actos verbales de los Estados cuentan como práctica estatal para la determinación de la posible existencia de una norma internacional consuetudinaria (En Comité Internacional de la Cruz Roja, 2005, p. xxxix). 
tudinario (Corte Internacional de Justicia, 1951, p. 25).

Para establecer la existencia de una regla de derecho internacional consuetudinario la práctica de los Estados debe ser uniforme, extensiva y representativa (Comité Internacional de la Cruz Roja, 2007). Esta será uniforme siempre que los diferentes Estados no registren una conducta diferente o incompatible entre ellos, es decir, que en general la práctica sea homogénea. Es extensiva cuando puede considerarse general mas no necesariamente universal. Finalmente, es representativa en aquellos casos en los que "Ios Estados especialmente afectados" o interesados tomen parte de la práctica determinada (Comité Internacional de la Cruz Roja, 2007). ${ }^{30}$

Para la presente investigación, el estudio de la práctica de los Estados, respecto al ejercicio de la jurisdicción universal sobre crímenes de guerra cometidos en conflictos armados internos que agreden el artículo común 3 de las Convenciones de Ginebra evidencia que esta es poco uniforme. Por un lado, se encuentran Estados que reconocen expresamente esta posibilidad, sobre los cuales no cabe duda de su aceptación y contribución al establecimiento de una regla

30 Este último requisito fue explicado por la Corte Internacional de Justicia en el caso North Sea Continental Shelf, donde se determinó que la práctica que resulta más importante es aquella que corresponde a los "Estados especialmente afectados" o interesados. Esto significa que no es esencial que todos los Estados tomen parte activa en la práctica, siempre y cuando se cuente con la participación, o por lo menos la aceptación, de aquellos Estados protagonistas en cada caso determinado. La Corte afirma que los Estados "especialmente afectados" siempre variarán según el caso. Para explicar lo último, apela al ejemplo del establecimiento de una regla consuetudinaria respecto a la prohibición del uso de cierta arma, caso en el cual resultará más relevante la práctica de aquellos Estados donde se fabrique ese tipo de armas y la de los principales países receptores de estas (Comité Internacional de la Cruz Roja, 2007, p. XLIV). consuetudinaria a favor de ese ejercicio. Otros, a pesar de no oponerse expresamente a esa práctica, no participan explícitamente de ella, dado que la ambigüedad de los términos legales que utilizan en sus legislaciones penales no permite determinar una posición certera al respecto. Finalmente, encontramos un grupo de Estados que tiene una práctica completamente contraria, pues es claro que sus legislaciones internas no permiten el ejercicio de esa forma de jurisdicción sobre los crímenes que nos conciernen. Así las cosas, la práctica de los Estados en el tema debatido no puede considerarse uniforme ni extendida.

En cuanto a la representatividad, es difícil determinar qué Estados serían los “especialmente afectados", dado que por tratarse del principio de jurisdicción universal, cualquiera podría tener interés en ello. Sin embargo, los Estados más representativos son aquellos que han sido o son escenario de conflictos armados internos, en los que se han cometido crímenes de guerra. De igual forma, también es relevante la opinión de los Estados en los cuales se asilen los presuntos autores de tales ofensas.

En cuanto a los primeros, de los países estudiados que reconocen expresamente el ejercicio de jurisdicción universal sobre crímenes de guerra cometidos en conflictos armados internos, Nicaragua, ${ }^{31}$ El Salvador, ${ }^{32}$ Eslovenia, Croacia ${ }^{33}$

\footnotetext{
31 Nicaragua fue escenario de una guerra civil entre finales de los 70 y los 80 .

32 El Salvador vivió un conflicto armado interno entre 1980 y 1992.

33 Tanto Eslovenia como Croacia fueron escenario del conflicto armado
} 
y el Congo ${ }^{34}$ han sufrido en su territorio conflictos armados de ese carácter. Países como Perú e Irlanda, que también vivieron conflictos armados internos, no prescriben la jurisdicción universal sobre crímenes de guerra cometidos en ese contexto.

Respecto a los segundos, se observa que Bélgica, Suiza, Países Bajos, Francia y Canadá, que han sido por excelencia lugar de asentamiento de personas que cometieron crímenes durante los conflictos armados en el continente africano y en la antigua Yugoslavia, han tramitado procesos penales en contra de los ofensores, sin que exista oposición por parte de otros Estados.

Finalmente, la praxis de organizaciones internacionales como el Comité Internacional de la Cruz Roja y Human Rights Watch contribuye al surgimiento de una norma consuetudinaria de jurisdicción universal en el caso estudiado pues, como se registró, estas afirman la existencia de esa costumbre.

\section{Opinio juris}

El segundo requerimiento para determinar la existencia de una norma de derecho internacional consuetudinario es que la práctica se dé porque el Estado considera que esa actuación es un derecho o una obligación (Comité Internacional de la Cruz Roja, 2007, p. xLv).

de la antigua Yugoslavia, que como se ha dicho en varias ocasiones, tuvo elementos de conflicto armado interno e internacional.

34 La República Democrática del Congo vivió un conflicto armado interno entre 1998 y 2003.
Adoptando el método utilizado por el estudio de derecho internacional consuetudinario auspiciado por el cIcr, se afirma que "la práctica estatal revela la existencia de una obligación cuando los Estados expresan la necesidad de que todos los demás tengan ese mismo comportamiento, o critican a los que actúan de manera diferente" (Comité Internacional de la Cruz Roja, 2007, p. xLv). Por otro lado, se evidencia la opinio juris de un derecho o permisión, en aquellos casos en los que "los Estados proceden de cierta manera sin que exista una obligación que imponga ese comportamiento y respecto a la cual no surgen protestas por parte de otros Estados" (Comité Internacional de la Cruz Roja, 2007, p. xLVI).

Frente al caso que nos concierne, en principio no se evidencia que la práctica de los Estados corresponda a una opinio juris encaminada a una obligación de carácter consuetudinario. ${ }^{35}$ Ello porque no se encuentra pronunciamiento estatal crítico contra aquellos Estados que no establecen la jurisdicción universal de sus Cortes sobre los crímenes objeto de estudio. Sin embargo, muchos Estados y organizaciones internacionales han reconocido el ejercicio de jurisdicción penal universal sobre crímenes de guerra cometidos en conflictos armados de carácter no internacional que transgreden el artículo común 3 de las Convenciones de Ginebra sin la oposición de otros, inclusive, de aquellos

35 Valga aclarar que la opinio juris de Bélgica está encaminada al reconocimiento de una obligación consuetudinaria al respecto. Esto fue manifestado por ese país durante el litigio ante la Corte Internacional de Justicia contra Senegal, en donde afirmó que existía una obligación consuetudinaria de ejercer jurisdicción universal sobre crímenes de guerra cometidos en conflictos armados no internacionales (Opinión separada del juez Abraham en Questions Relating to the Obligation to Prosecute or Extradite, 2012). 
que podrían verse afectados. Esto último permite sostener que la opinio juris de esta práctica está encaminada a la evocación de un derecho o permición internacional consuetudinaria al respecto.

Finalmente, resulta acertado reconocer el impacto que ha tenido el Estatuto de la Corte Penal Internacional sobre la opinio juris de los Estados parte. Este instrumento ha impulsado a las autoridades nacionales a criminalizar las conductas contenidas en esa Convención y a reconocer el ejercicio de la jurisdicción universal de sus Cortes nacionales sobre esas atrocidades, en las que se incluyen los crímenes de guerra cometidos en conflictos armados internos que violan el artículo común 3 de las Convenciones de Ginebra.

\section{CONCLUSIONES}

La jurisdicción universal permite que un Estado afirme y aplique sus normas penales domésticas sobre individuos extranjeros que hayan cometido crímenes en el territorio de otro, en perjuicio de ciudadanos extranjeros y por conductas que no afectan intereses directos del Estado, buscando evitar la impunidad frente a crímenes que se consideran atroces por la comunidad internacional. Su ejercicio resulta obligatorio en los casos en que el derecho internacional así lo determine a través de una norma convencional o consuetudinaria, mientras que la forma como se ejercite es un aspecto que corresponde fijar soberanamente a los Estados en sus normas internas, las cuales deberán definir si permite su adjudicación aún en ausencia del presunto criminal en el territorio.

En cuanto al ejercicio de la jurisdicción universal sobre crímenes de guerra cometidos en conflictos armados internos el derecho internacional convencional guarda silencio. Por su parte, el estudio realizado rebela que la práctica de los Estados es al respecto no uniforme ni suficientemente extendida para poderla considerar una práctica generalizada.

Finalmente, debe recordarse que en la actualidad la mayoría de los conflictos armados son de carácter interno, y que en su desarrollo se cometen crímenes que por su dimensión y gravedad son rechazados por la comunidad internacional, que ha optado por aclamar la criminalidad de estas infracciones a nivel internacional. Además, las consecuencias causadas sobre la población civil en un conflicto armado interno son igual de atroces a las ocasionadas por conflictos armados internacionales, por lo cual "no hay una justificación moral o legal realmente persuasiva para tratar a los perpetradores de atrocidades cometidas en conflictos armados internos con más benevolencia que a aquellos que cometen el mismo tipo de atrocidades en conflictos internacionales" (Meron, 1995, p. 561).

\section{Referencias}

Akehurst, M. (1974). Jurisdiction in the International Law. British Yearbook of International Law, 46, 145-257. 
Asamblea General de las Naciones Unidas. (2010). The Scope and Application of the Principle of Universal Jurisdiction (A/RES/64/117 del 15 de enero de 2010).

Association of International Law. (2000). London Conference, 25-29 July 2000. Final Report on the Excersice of Universal Jurisdiction in Respect of Gross Human Rights Offences. Committee on International Human Rights Law and Practice.

Cassese, A. (2003). Is the Bell Tolling for Universality? A Plea for Sensible Notion of Universal Jurisdiction. Journal of International Criminal Justice, 1 (3), 589-595.

Comité Internacional de la Cruz Roja. (2005). Customary International Humanitarian Law (Vol. II: Práctica). J. M. Henckaerts y L. Doswald-Beck (Edits.). Cambridge: Cambridge University Press.

Comité Internacional de la Cruz Roja. (2007). El derecho internacional humanitario consuetudinario (Vol. I: Normas). J. M. Henckaerts y L. Doswald-Beck (Edits.). M. S. García (Trad.). Buenos Aires, Argentina: Comité Internacional de la Cruz Roja.

Comité Internacional de la Cruz Roja. Convenciones de Ginebra (aprobadas el 12 de agosto de 1949 por la Conferencia Diplomática para Elaborar Convenios Internacionales destinados a proteger a las víctimas de la guerra, celebrada en Ginebra del 12 de abril al 12 de agosto de 1949).
Corte Internacional de Justicia. (14 de febrero de 2002). Arrest Warrant of 11 April 2000 (Democratic Republic of the Congo v. Belgium).

Corte Internacional de Justicia. (1 de julio de 2010). Reports of Judgments Advisory Opinionand Orders. Questions Relating to the Obligation to Prosecute or Extradite (Belgium v. Senegal).

Corte Penal Internacional para la antigua Yugoslavia. (2 de octubre de 1995). Presecutor v. Tadic. Decision on the Defense Motion for Interlocutory Appeal on Jurisdiction.

Corte Permanente de Justicia Internacional. (7 de septiembre de 1927). Caso S. S. Lotus Fr. v. Turk, n. ${ }^{\circ}$ 9. Arrest Warrant, 2000, opinión separada de los jueces Higgins, Kooijmans (...).

Council of the European Union. (16 de abril de 2009). The Au-EU Expert Report on the Principle of Universal Jurisdiction, 8672/1/09 Rev. 1.

Human Rights Watch. (2000). The Pinochet Precedent: How Victims Can Pursue Human Rights Criminals Abroad. H. R. Watch (Ed.). New York: Association of International Law.

Institute of International Law. (2005). Universal Criminal Jurisdiction with regard to the crimen of genocide, crimes against humanity and war crimes. Reporte n. ${ }^{\circ}$, Comisión 17.

Kress, C. (2006). Universal Jurisdiction over International Crimes and the Institut de Droit In- 
ternational. Journal of International Criminal Justice (4), 561-585.

La Haye, E. (2008). War Crimes in International Armed Conflicts. Cambridge: Cambridge University Press.

Meron, T. (1995). International Criminalization of Internal Atrocities. American Journal of International Law, 89, 554-577.

Moir, L. (2009). Grave Breaches and Internal Armed conflicts. Journal of International Criminal Law, (7), 763-787.

O`Keefe, R. (2004). Universal Jurisdiction. Clarifying the Basic Concept. Journal of International Criminal Justice, 2, 735-760.

O`Keefe, R. (2009). The Grave Breaches Regime and Universal Jurisdiction. Journal of International Criminal Justice (7), 811-831.

Organización de las Naciones Unidas. (17 de julio de 1998). Estatuto de Roma de la Corte Penal Internacional.

Organización de las Naciones Unidas. (Junio 26 de 1945). Estatuto de la Corte Internacional de Justicia.

Organización de las Naciones Unidas. Consejo de Seguridad. (14 de agosto de 2000). Estatuto para la Corte Especial de Sierra Leona. (Resolución 1315/2000).

Organización de las Naciones Unidas. Consejo de Seguridad. (8 de noviembre de 1994). Estatuto del Tribunal Internacional para Ruanda (Resolución 955/1994).
Organización de las Naciones Unidas. Convención de Viena sobre el Derecho de Ios Tratados (hecha en Viena, Austria, el 23 de mayo de 1969; entró en vigor el 27 de enero de 1980).

Redress y Fidh. (December, 2010). Extraterritorial Jurisdiction in the European Union. A Study of the Laws and Practice in the 27 Member States of the European Union.

Reydams, L. (2004). Universal Jurisdiction. Oxford Scholarship.

Reydams, L. (2010). The Rise and Fall of Universal Jurisdiction. Belgium: University of Notre Dame K. U. Leuven.

Ryngaert, C. (2007). Universal Jurisdiction over Genocide and Wartime Torture in Dutch Courts: An Appraisal of Afghan and Rwandan cases. Hague Justice Journal, 2 (2).

Werle, G. (2011). Tratado de Derecho Penal Internacional. (2a edición). Valencia, España: Tirant lo Blanch. 


\section{ANEXO \\ Práctica legal de los Estados}

\begin{tabular}{|c|c|}
\hline \multicolumn{2}{|c|}{$\begin{array}{l}\text { 1. Estados que explícitamente afirman jurisdicción universal sobre crímenes de guerra cometidos en conflictos arma- } \\
\text { dos no internacionales. }\end{array}$} \\
\hline ESTADO & REGLAMENTACIÓN \\
\hline Holanda & $\begin{array}{l}\text { Acta de Crímenes Internacionales de } 2003 \text { (secciones } 1 \text { y 6). Establece expresamente la ju- } \\
\text { risdicción universal de sus Cortes respecto a criminales que cometan violaciones al artículo } \\
\text { común } 3 \text { de las Convenciones de Ginebra en el transcurso de un conflicto armado interno. }\end{array}$ \\
\hline Burundi & $\begin{array}{l}\text { El artículo } 24 \text { del Código Penal de Burundi (Ley del } 8 \text { de mayo de 2003) establece la jurisdic- } \\
\text { ción de las Cortes nacionales sobre personas que, así no sean residentes de ese Estado o no } \\
\text { estén presentes en su territorio, sean sospechosas de haber cometido crímenes de guerra en } \\
\text { conflictos armados internos. }\end{array}$ \\
\hline Canadá & $\begin{array}{l}\text { El Acta de Crímenes Contra la Humanidad y Crímenes de Guerra de } 2000 \text { permite que las } \\
\text { Cortes canadienses ejerzan jurisdicción universal sobre crímenes de guerra cometidos en con- } \\
\text { flictos armados internos (sección 6), siempre y cuando el presunto autor se encuentre en el } \\
\text { territorio nacional de ese país. }\end{array}$ \\
\hline Alemania & $\begin{array}{l}\text { El Código de Crímenes contra el Derecho Internacional, que entró en vigencia en junio de 2002, } \\
\text { establece jurisdicción universal respecto a crímenes de guerra cometidos en conflictos arma- } \\
\text { dos no internacionales (sección 8) que puede ser ejercida incluso in absentia. }\end{array}$ \\
\hline Rumania & $\begin{array}{l}\text { El Código Penal de Rumania de } 2009 \text { estipula el principio de jurisdicción universal sobre } \\
\text { crímenes de guerra cometidos en conflictos armados no internacionales siempre que se cuente } \\
\text { con la presencia del presunto criminal (arts. } 11 \text { y 440). }\end{array}$ \\
\hline Bélgica & $\begin{array}{l}\text { El Código Penal belga permite ejercer jurisdicción universal sobre crímenes de guerra que at- } \\
\text { enten contra el artículo común } 3 \text { de las Convenciones de Ginebra (art. 136, sección 2), siempre } \\
\text { y cuando el presunto criminal tenga su residencia principal en Bélgica y que el fiscal público sea } \\
\text { quien inicie el proceso después de asegurarse que las víctimas o sus familiares han denunciado } \\
\text { los hechos en el lugar donde ocurrieron y que ese Estado no se oponga a que Bélgica castigue } \\
\text { esos actos. }\end{array}$ \\
\hline Nicaragua & $\begin{array}{l}\text { El Código Penal de Nicaragua establece en su artículo } 16.3 \text { la posibilidad de ejercer jurisdicción } \\
\text { universal sobre personas que, en el curso de un conflicto armado internacional o de una guerra } \\
\text { civil, cometan serias infracciones a las Convenciones de Ginebra. }\end{array}$ \\
\hline El Salvador & $\begin{array}{l}\text { El artículo } 10 \text { del Código Penal de El Salvador establece la jurisdicción universal sobre aquellos } \\
\text { que cometan crímenes que atentan contra las costumbres y leyes de la guerra tanto en conflic- } \\
\text { tos armados internos como internacionales. }\end{array}$ \\
\hline Finlandia & $\begin{array}{l}\text { Finlandia hace parte de este grupo de países dado que la sección } 7 \text { del capítulo } 1 \text { y la sección } \\
5 \text { de capítulo } 11 \text { del Código Penal de ese Estado afirman la jurisdicción universal de sus Cortes } \\
\text { sobre crímenes de guerra cometidos en conflictos armados internos. }\end{array}$ \\
\hline Suiza & $\begin{array}{l}\text { El artículo } 6 \text { del Código Penal Suizo establece la jurisdicción universal de las Cortes nacionales } \\
\text { respecto a cualquier persona que cometa un crimen que dicho Estado esté obligado a enjui- } \\
\text { ciar bajo un tratado. Esa provisión es complementada por el artículo } 264 \text { (b) el cual establece } \\
\text { expresamente la jurisdicción universal sobre crímenes de guerra cometidos en conflictos ar- } \\
\text { mados no internacionales. }\end{array}$ \\
\hline Eslovenia & $\begin{array}{l}\text { Eslovenia también hace parte de este grupo en razón a que el numeral } 3 \text { del artículo } 102 \text { de su } \\
\text { Código Penal establece expresamente la jurisdicción universal de sus Cortes sobre violaciones } \\
\text { al artículo común } 3 \text { de las Convenciones de Ginebra. }\end{array}$ \\
\hline
\end{tabular}




\section{Estados que establecen jurisdicción universal sobre los crímenes que se encuentran en el Estatuto de Roma}

\begin{tabular}{|c|c|}
\hline Francia & $\begin{array}{l}\text { En el } 2010 \text { modificó su Código Penal y de Procedimiento para ajustar su legislación al Estatuto } \\
\text { de Roma, afirmando la jurisdicción universal de sus Cortes sobre los diferentes crímenes tipi- } \\
\text { ficados en el Estatuto de la Corte Penal Internacional (Ley } 930 \text { del } 9 \text { de agosto de 2010). }\end{array}$ \\
\hline Croacia & $\begin{array}{l}\text { El artículo } 14 \text { (1) de su Código Penal afirma la aplicación de sus leyes penales sobre cualquiera } \\
\text { que cometa, fuera del territorio croata, un delito frente al cual ese Estado esté obligado a en- } \\
\text { juiciar bajo una norma de derecho internacional. De igual forma, el } 4 \text { de noviembre de } 2003 \\
\text { Croacia expidió la Ley que autoriza el ejercicio de jurisdicción universal para castigar los delitos } \\
\text { estipulados en el Estatuto de la Corte Penal Internacional (art. 10). }\end{array}$ \\
\hline $\begin{array}{l}\text { República Democráti- } \\
\text { ca del Congo }\end{array}$ & $\begin{array}{l}\text { El artículo } 4 \text { del Código Penal del Congo extiende la jurisdicción universal sobre todos los } \\
\text { crímenes definidos en el Estatuto de Roma, siempre que el presunto criminal esté presente en } \\
\text { el fórum del Estado cuando se abran las investigaciones. }\end{array}$ \\
\hline Nueva Zelanda & $\begin{array}{l}\text { El Acta de Crímenes Internacionales y de la Corte Penal Internacional del 2000, establece la } \\
\text { jurisdicción universal de las Cortes de ese Estado frente a los crímenes de genocidio, lesa hu- } \\
\text { manidad y crímenes de guerra definidos en el Estatuto de Roma. }\end{array}$ \\
\hline Australia & $\begin{array}{l}\text { El Acta de la Corte Penal Internacional de 2002, que modificó el Código Penal australiano de } \\
1995 \text {, incorporó el principio de jurisdicción universal sobre los crímenes establecidos en el } \\
\text { Estatuto de Roma. }\end{array}$ \\
\hline Sur África & $\begin{array}{l}\text { El Acta de la Corte Penal Internacional de } 2002 \text { extiende la jurisdicción universal de las Cortes } \\
\text { sur africanas sobre todos los crímenes tipificados en el Estatuto de Roma siempre y cuando el } \\
\text { autor se encuentre presente. }\end{array}$ \\
\hline Argentina & $\begin{array}{l}\text { La Ley Argentina de Implementación del Estatuto de Roma de la Corte Penal Internacional (Ley } \\
26 \text { del } 13 \text { de diciembre de 2006), abre la posibilidad de ejercer jurisdicción universal por sus } \\
\text { Cortes nacionales sobre los crímenes del Estatuto de Roma. }\end{array}$ \\
\hline Uruguay & $\begin{array}{l}\text { Su Ley de Cooperación con la Corte Penal Internacional en materia de lucha contra el genoci- } \\
\left.\text { dio, crímenes de guerra y crímenes de lesa humanidad (n. }{ }^{\circ} 18 / 026\right) \text { del } 4 \text { de octubre de } 2006 \text {, } \\
\text { permite el ejercicio del principio de universalidad sobre los crímenes del Estatuto de Roma. }\end{array}$ \\
\hline Eslovaquia & $\begin{array}{l}\text { El Código Penal de } 2005 \text { establece el principio de jurisdicción universal respecto a varios } \\
\text { crímenes de guerra (sección 5a), sin hacer referencia a que sean cometidos en conflictos arma- } \\
\text { dos internacionales o internos. Sin embargo, el artículo } 433 \text { establece la jurisdicción respecto a } \\
\text { los crímenes de guerra contenidos en el art. } 8 \text { del Estatuto de Roma, donde figuran los cometi- } \\
\text { dos en conflictos armados internos. }\end{array}$ \\
\hline Portugal & $\begin{array}{l}\text { La Ley } 31 / 2004 \text { incorpora en el derecho penal portugués los delitos establecidos en el Estatuto } \\
\text { de la Corte Penal Internacional, y señala que estos podrán ser juzgados en ese país bajo lo esta- } \\
\text { blecido en el artículo } 5 \text { del Código Penal, el cual incorpora el principio de jurisdicción universal, } \\
\text { siempre que se encuentre presente el sospechoso. }\end{array}$ \\
\hline Chipre & $\begin{array}{l}\text { La Ley por medio de la cual se ratifica el Estatuto de la Corte Penal Internacional (Ley } 8 \text { (III)/2002 } \\
\text { modificada por la Ley } 23(\text { (III)/2006) establece la jurisdicción universal de las Cortes cipreses re- } \\
\text { specto a los crímenes contenidos en ese Estatuto (sección 6). }\end{array}$ \\
\hline
\end{tabular}

3. Estados que autorizan el ejercicio de jurisdicción universal sobre crímenes de guerra sin diferenciar aquellos cometidos en conflictos armados internos o internacionales

\begin{tabular}{|l|l|}
\hline Azerbaiyán & $\begin{array}{l}\text { El artículo } 12 \text { numeral } 3 \text { del Código Penal de } 1999 \text { establece la jurisdicción universal de sus Cor- } \\
\text { tes nacionales sobre crímenes de guerra. Estos son definidos en su ley penal como violaciones } \\
\text { a las normas del derecho internacional humanitario en tiempos de guerra. }\end{array}$ \\
\hline Belarus & $\begin{array}{l}\text { El artículo } 6 \text { del Código Penal de esta República permite ejercer jurisdicción universal sobre } \\
\text { crímenes de guerra, los cuales son definidos por el mismo código y cubren aquellos cometidos } \\
\text { en conflictos armados internos (art. 134). }\end{array}$ \\
\hline
\end{tabular}




\begin{tabular}{|c|c|}
\hline Colombia & $\begin{array}{l}\text { El numeral } 5 \text { del artículo } 16 \text { del Código Penal colombiano establece que se podrá ejercer juris- } \\
\text { dicción frente "al extranjero que haya cometido en el exterior un delito en perjuicio de extran- } \\
\text { jero, siempre que se reúnan estas condiciones: a) Que se halle en territorio colombiano; b) Que } \\
\text { el delito tenga señalada en Colombia pena privativa de la libertad cuyo mínimo no sea inferior } \\
\text { a tres (3) años; c) Que no se trate de delito político, y d) Que solicitada la extradición no hubiere } \\
\text { sido concedida por el gobierno colombiano. Cuando la extradición no fuere aceptada habrá } \\
\text { lugar a proceso penal. Por su parte, el Título Il del Segundo Libro del mismo Código (arts. } 135 \text { y } \\
\text { ss.) tipifica penas mayores a tres años por delitos contra personas protegidas por el derecho in- } \\
\text { ternacional humanitario, sin hacer distinción alguna respecto al carácter del conflicto armado. }\end{array}$ \\
\hline Costa Rica & $\begin{array}{l}\text { El artículo } 7 \text { del Código Penal Costarricense reza: "[i]ndependientemente de las disposiciones } \\
\text { vigentes en el lugar de la comisión del hecho punible y la nacionalidad del autor, se penará, } \\
\text { conforme a la ley costarricense, a quienes cometan actos de piratería, terrorismo o su finan- } \\
\text { ciamiento, o actos de genocidio; falsifiquen monedas, títulos de crédito, billetes de banco y } \\
\text { otros efectos al portador; trafiquen, ilícitamente, armas, municiones, explosivos o materiales } \\
\text { relacionados; tomen parte en la trata de esclavos, mujeres o niños; se ocupen del tráfico de } \\
\text { estupefacientes o de publicaciones obscenas; asimismo, se penará a quienes cometan otros } \\
\text { hechos punibles contra los derechos humanos y el derecho internacional humanitario, previs- } \\
\text { tos en los tratados suscritos por Costa Rica o en este Código". }\end{array}$ \\
\hline Dinamarca & $\begin{array}{l}\text { El artículo } 8 \text { (1) (6) del Código Penal danés establece la posibilidad de ejercer jurisdicción uni- } \\
\text { versal sobre crímenes de guerra bajo las siguientes condiciones: en primer lugar que otro Es- } \\
\text { tado haya solicitado extradición de la persona en cuestión y que esta haya sido negada por } \\
\text { las autoridades danesas. En segundo lugar, que el crimen esté tipificado en Dinamarca. Esta } \\
\text { norma es complementada por el Código Penal Militar (Acta n. }{ }^{\circ} 530 \text { del } 24 \text { de junio de } 2005 \text {, } \\
\text { capítulo } 1 \text { sección } 2 \text { ) donde se establece la jurisdicción sobre crímenes de guerra. }\end{array}$ \\
\hline Estonia & $\begin{array}{l}\text { La sección } 8 \text { del Código Penal de ese Estado afirma la jurisdicción universal de sus Cortes na- } \\
\text { cionales sobre actos respecto a los cuales Estonia esté obligado a investigar y juzgar bajo un } \\
\text { tratado internacional. Además, establece esa jurisdicción sobre crímenes de guerra sin diferen- } \\
\text { ciar entre los de carácter internacional o interno (capítulo 8, división 4). }\end{array}$ \\
\hline Etiopía & $\begin{array}{l}\text { El artículo } 17 \text { (1) de su Código Penal afirma la jurisdicción universal de sus Cortes nacionales } \\
\text { sobre "cualquier persona que haya cometido en un país extranjero una ofensa en contra del } \\
\text { derecho internacional o una que esté tipificada en la legislación de Etiopía, o una que obedezca } \\
\text { a la obligación que se desprende de un tratado del cual Etiopía sea parte. Como puede obser- } \\
\text { varse, la legislación de este país es sumamente amplia, por lo cual podría permitir el ejercicio } \\
\text { de jurisdicción universal sobre infracciones al artículo común } 3 \text { de las Convenciones de Ginebra } \\
\text { en conflictos armados internos. }\end{array}$ \\
\hline Georgia & $\begin{array}{l}\text { El caso de Georgia es particular pues el Código Penal de ese Estado, en el tercer inciso del artí- } \\
\text { culo 5, establece la jurisdicción universal de sus Cortes sobre aquellos que "hayan cometido } \\
\text { una acción que bajo este Código genere responsabilidad penal (...) o si la responsabilidad penal } \\
\text { se establece por un tratado internacional del que Georgia haga parte". Dado que este país } \\
\text { ratificó el Estatuto de Roma en el } 2003 \text {, podría ejercerse jurisdicción universal sobre las viola- } \\
\text { ciones al artículo común } 3 \text { de las Convenciones de Ginebra a partir de la criminalización que se } \\
\text { hace en ese instrumento. }\end{array}$ \\
\hline Lituania & $\begin{array}{l}\text { El Código Penal de este país afirma la jurisdicción universal de sus Cortes en caso de crímenes } \\
\text { internacionales dispuestos en tratados (art. 7). Sin embargo, el capítulo destinado a la defin- } \\
\text { ición de estas ofensas (capítulo XV), contiene una definición vaga de los crímenes de guerra en } \\
\text { los que se tendrá jurisdicción, pues establece que estos serán los cometidos en "tiempos de } \\
\text { guerra o de conflicto armado internacional u ocupación". Se podría llegar a pensar que "tiem- } \\
\text { pos de guerra" cubre aquellos crímenes cometidos en conflictos armados internos. }\end{array}$ \\
\hline
\end{tabular}




\begin{tabular}{|c|c|}
\hline España & $\begin{array}{l}\text { Por un lado, el numeral 40 del artículo } 23 \text { de la Ley Orgánica del Poder Judicial español 6/1985 } \\
\text { regula la aplicación del principio de justicia universal. Este afirma que la ley española es apli- } \\
\text { cable a ciertos delitos que afectan a bienes jurídicos declarados supranacionales, con indepen- } \\
\text { dencia del lugar de la comisión de los hechos o la nacionalidad de los implicados. Este artículo } \\
\text { fue reformado por la Ley Orgánica } 1 / 2014 \text { del } 13 \text { de marzo. }\end{array}$ \\
\hline Tayikistán & $\begin{array}{l}\text { El artículo } 15 \text { del Código Penal establece que los extranjeros serán responsables bajo la ley } \\
\text { penal por crímenes cometidos en el territorio de otro Estado que sean delitos previstos en las } \\
\text { reglas del derecho internacional reconocidas por la República de Tayikistán. Aunque la pro- } \\
\text { visión de las leyes penales de este Estado es un poco ambigua, podría ser extendida a crímenes } \\
\text { de guerra que atenten contra el artículo común } 3 \text { de las Convenciones de Ginebra. }\end{array}$ \\
\hline Suecia & $\begin{array}{l}\text { El Código Penal sueco afirma la jurisdicción universal de sus Cortes frente a crímenes que bajo } \\
\text { la ley penal de ese Estado tengan una pena mayor de seis meses, siempre que el autor esté pre- } \\
\text { sente en el territorio nacional (capítulo 2, sección 2). Por su parte, la sección } 6 \text { del capítulo } 22 \\
\text { criminaliza las infracciones al derecho internacional humanitario sin distinguir entre conflictos } \\
\text { armados internacionales o internos. }\end{array}$ \\
\hline Polonia & $\begin{array}{l}\text { El Código Penal polaco permite ejercer jurisdicción universal sobre presuntos autores de deli- } \\
\text { tos que en su derecho nacional tengan una pena que exceda los dos años de prisión. Se requi- } \\
\text { ere que el sospechoso se encuentre dentro de Polonia y que no se haya tomado una decisión } \\
\text { para su extradición (art. } 110 \text { numeral } 2 \text { - } \text { ). Por su parte, el artículo } 123 \text { del mismo Código esta- } \\
\text { blece una pena mínima de doce años frente a los crímenes de guerra, sin distinguir que estos } \\
\text { hayan sido cometidos en conflictos armados internos o internacionales. }\end{array}$ \\
\hline Noruega & $\begin{array}{l}\text { El Código General Penal Civil de } 2005 \text { establece el principio de jurisdicción universal sobre } \\
\text { crímenes de guerra sin hacer ninguna distinción respecto a que sean cometidos en conflictos } \\
\text { armados internacionales o internos (sección 103, capítulo 16). }\end{array}$ \\
\hline Luxemburgo & $\begin{array}{l}\text { La Ley del } 9 \text { de enero de } 1985 \text { establece la posibilidad de ejercer jurisdicción universal sobre } \\
\text { crímenes de guerra que atenten contra personas protegidas por las Convenciones de Ginebra } \\
\text { de } 1949 \text {, sin identificar la naturaleza del conflicto armado (art. 10). }\end{array}$ \\
\hline República Checa & $\begin{array}{l}\text { El nuevo Código Penal de } 2009 \text { permite el ejercicio de jurisdicción universal sobre crímenes de } \\
\text { guerra, los cuales son definidos en el art. 412, sin hacer referencia al tipo de conflicto armado } \\
\text { (Acta n. 40/2009). }\end{array}$ \\
\hline Bulgaria & $\begin{array}{l}\text { El Código Penal búlgaro establece la posibilidad de ejercer jurisdicción universal respecto a } \\
\text { cualquiera que haya cometido un crimen en contra de la paz y la humanidad (art. 5). El artículo } \\
412 \text {, que se encuentra bajo el capítulo de Crímenes en Contra de la Paz y la Humanidad, tipifica } \\
\text { los crímenes de guerra contra civiles sin hacer mención del carácter del conflicto armado. }\end{array}$ \\
\hline \multicolumn{2}{|c|}{$\begin{array}{l}\text { 4. Estados que confieren jurisdicción universal únicamente respecto a los crímenes de guerra que configuran una in- } \\
\text { fracción grave a los Convenios de Ginebra de } 1949\end{array}$} \\
\hline Hungría & $\begin{array}{l}\text { El Código Penal de Hungría establece la aplicación de sus normas penales universalmente cu- } \\
\text { ando se trata de ciertos crímenes internacionales tipificados en el capítulo XI de dicho Código. } \\
\text { El título II de ese capítulo está dirigido a crímenes de guerra pero por su descripción parece di- } \\
\text { rigirse solo a aquellos que configuran infracciones graves a las Convenciones de Ginebra (siem- } \\
\text { pre habla de la población civil del "territorio ocupado"). }\end{array}$ \\
\hline Irlanda & $\begin{array}{l}\text { Las normas penales irlandesas solo pueden ser aplicadas bajo el principio de jurisdicción uni- } \\
\text { versal sobre delitos que configuren una infracción grave a las Convenciones de Ginebra (Acta } \\
\text { de la Convención de Ginebra, 1962, modificada en 1998, sección 3; Acta de la Corte Penal } \\
\text { Internacional, 2006, sección 66). }\end{array}$ \\
\hline Reino Unido & $\begin{array}{l}\text { El Acta de las Convenciones de Ginebra de } 1957 \text { (sección 1.1) solo permite el ejercicio de juris- } \\
\text { dicción universal sobre infracciones graves a las Convenciones de Ginebra. }\end{array}$ \\
\hline
\end{tabular}




\begin{tabular}{|c|c|}
\hline Italia & $\begin{array}{l}\text { Bajo las leyes penales italianas solo es posible ejercer jurisdicción universal sobre crímenes } \\
\text { de guerra que configuren una infracción grave a las Convenciones de Ginebra (Ley } 962 \text { del } 9 \\
\text { de octubre de } 1967 \text { y Código Penal Militar de } 1941 \text { modificado en el 2002). Sin embargo, este } \\
\text { último está en proceso de implementar nuevas leyes para ajustar su ordenamiento penal al } \\
\text { Estatuto de Roma, y en tales proyectos pretende incluir la posibilidad de ejercer jurisdicción } \\
\text { universal sobre los crímenes que tipifica ese Estatuto (Proyecto del Ley n. } 2724 \text {, art. } 15 \text { en } \\
\text { Amnistía Internacional). }\end{array}$ \\
\hline \multicolumn{2}{|c|}{$\begin{array}{l}\text { 5. Estados que solo afirman su jurisdicción universal en aquellos casos en los que sea una obligación impuesta por una } \\
\text { norma de derecho internacional convencional }\end{array}$} \\
\hline Rusia & $\begin{array}{l}\text { La Federación Rusa no prevé jurisdicción universal sobre crímenes de guerra cometidos en } \\
\text { conflictos armados internos. El art. } 12 \text { (3) solo permite este tipo de jurisdicción cuando Rusia } \\
\text { este obligado por un tratado internacional (Código Penal de la Federación Rusa, n. }{ }^{\circ} 63-\mathrm{FZ} \text { del } \\
13 \text { de junio de 1996). }\end{array}$ \\
\hline Perú & $\begin{array}{l}\text { El Código Penal de Perú (Decreto Legislativo n. }{ }^{\circ} 635 \text { del } 8 \text { de abril de } 1991 \text { ) solo establece el } \\
\text { ejercicio de jurisdicción universal respecto a crímenes que un tratado internacional lo obligue } \\
\text { a enjuiciar. }\end{array}$ \\
\hline Brasil & $\begin{array}{l}\text { El Código Penal de Brasil (Decreto Ley } \mathrm{n}^{\circ} 2.848 \text { del } 7 \text { de diciembre de 1940) solo permite el } \\
\text { ejercicio de jurisdicción universal respecto a crímenes de genocidio y aquellos a los que esté } \\
\text { obligado en virtud de un tratado internacional (art. 7). }\end{array}$ \\
\hline \multicolumn{2}{|l|}{ 6. Otros } \\
\hline Estados Unidos & $\begin{array}{l}\text { Las leyes de Estados Unidos solo permiten ejercer jurisdicción universal sobre actos de tor- } \\
\text { tura. }\end{array}$ \\
\hline Grecia & $\begin{array}{l}\text { El Código Penal Griego (Ley n. }{ }^{\circ} 3003 / 2002 \text {, art. 8) establece jurisdicción universal sobre algu- } \\
\text { nos delitos, pero entre ellos no se encuentra ningún crimen de guerra. }\end{array}$ \\
\hline Austria & $\begin{array}{l}\text { La sección } 64 \text { del Código Criminal de Austria no contempla la posibilidad de ejercer jurisdic- } \\
\text { ción universal sobre crímenes de guerra. }\end{array}$ \\
\hline
\end{tabular}

